J. Product. \& Dev., 22(2): 323- 337 (2017)

\title{
EFFECT OF SOME PLANT EXTRACTS ON GROWTH AND NUTRITIONAL STATUS OF FLAME SEEDLESS GRAPEVINE TRANSPLANTS
}

\author{
A. M. M. A. Akl*; M. A.M. Abada** and Fatma F. A. Gadalla* \\ *Hort. Dept. Fac. of Agric. Minia Univ. Egypt. \\ ** Viticulture Res. Dept. Hort. Instit. ARC. Giza, Egypt
}

\begin{abstract}
A pot experiment was conducted during 2014 and 2015 seasons to test the efficacy of eleven plant extracts (seven oils of garlic, onion, peppermint, olive, clove, flax seed and anise plus four extracts of turmeric, green tea, moringa leaf and red chillies) each at 5\% on growth and nutritional status of Flame seedless grapevine transplants.

Results showed that the previous eleven plant extracts were very effective in enhancing all growth aspects (plant height, stem thickness, number of leaves/plant, number of lateral shoots/plant, main shoot length, number of leaves/shoot, leaf area and dry weight of whole plant), root parameters (root distribution area, number of secondary roots per main root, main root length and dry weight of roots/plant), leaf pigments (chlorophylls $a \& b$, total chlorophylls and total carotenoids), percentages of total carbohydrates and soluble sugars in the leaves and uptake of $N, P$ and $K$ by transplant over the check treatment. The best plant extracts in this respect could be arranged as follows in descending order garlic oil, turmeric extract, onion oil, green tea extract, moringa leaf extract, red chillies extract, peppermint oil, clove oil, olive oil, flax seed oil and anise oil.

Conclusively, for producing vigorous flame seedless grapevine transplants, it is necessary to spray the one-year old transplant with garlic oil or turmeric extract each at 5\% four times at the middle of April, May, June and July yearly.
\end{abstract}

Keywords: Flame seedless grapevine transplants, plant extracts, growth, vine nutritional status.

\section{INTRODUCTION}

Recently, more efforts were done to eliminate the use of synthetic substances throughout agricultural and horticultural practices for improving yield and fruit quality. Using natural plant extracts was the new alternative 
compounds for improving yield and fruit quality as safety agents for human and environment.

Plant extracts are characterized by their higher content of organsosulfur compounds, volatile components, fats, proteins, nutrients, tannins, vitamins and antioxidants (Peter, 1999). Therefore, these plant extracts is considered as a source of antioxidants and nutrients supplying the plants with their requirements from all antioxidants and nutrients. Their antioxidative properties appeared for preventing reactive oxygen species (Bhanu et al., 2013).

Previous studies supported the essential roles of plant extracts on growth and nutritional status of the trees (Abdelaal and Aly, 2013; Ahmed et al., 2013; Abada, 2014; Ahmed et al., 2014; Ahmed et al., 2015; Ahmed, 2016; Abada et al., 2017; Ibrahim-Asmaa, 2017 and Farag-Rana, 2017).

Therefore, the target of this study was examining the effect of different plant extracts (seven oils of garlic, onion, peppermint, olive, clove, flax seed and anise plus four extracts of turmeric, green tea, moringa leaf and red chillies) each at $5 \%$ on growth and nutritional status of Flame seedless grapevine transplants.

\section{MATERIALS AND METHODS}

This pot experiment was carried out during 2014 and 2015 seasons on 180 uniform in vigour 1-year- old of Flame seedless grapevine transplants. The selected vine transplants are grown in a nursery located in Faculty of Agric., Minia Univ., Minia Governorate, where the texture of the soil used is clay (Table 1). Soil analysis was done according to the procedures that outlined by Wilde et al., (1985).

Table (1): Analysis of the tested soil.

\begin{tabular}{|l|c|}
\hline Constituents & Values \\
\hline Sand \% & 4.0 \\
\hline Silt \% & 13.0 \\
\hline Clay \% & 83.0 \\
\hline Texture & Clay \\
\hline O.M. \% & 2.41 \\
\hline pH (1:2.5 extract) & 7.69 \\
\hline E.C (1: 2.5 extract) (mmhos/ ICM/ 25 $\mathbf{~ C ) ~}$ & 0.91 \\
\hline CaCO \% & 1.55 \\
\hline Total N \% & 0.09 \\
\hline Available P (ppm/ Olsen) & 5.9 \\
\hline Available K (ppm, ammonium acetate) & 490 \\
\hline
\end{tabular}


All transplants of Flame seedless grapevines received $10 \mathrm{~g}$ of ammonium sulphate, calcium superphosphate and potassium sulphate during each seasons. These fertilizers were divided into five batches applied as $2 \mathrm{~g}$ monthly started on the middle of April. The transplants were planted the first week of March during both seasons. Another horticultural practices such as pest management and removing weeds were carried out as usual.

This study consisted from the following twelve treatments from different plant at $5 \%$ to the control treatment as follows:

1- Control (sprayed with water vines).

2- Spraying garlic oil.

3- Spraying turmeric extract.

4- Spraying onion oil.

5- Spraying green tea extract.

6- Spraying moringa leaf extract.

7- Spraying red chillies extract.

8- Spraying peppermint oil.

9- Spraying clove oil.

10- Spraying olive oil.

11- Spraying flax seed oil.

12- Spraying anise oil

Each treatment was replicated three times five vine transplants per each. The selected transplants were grown in clay pots $25 \times 50 \mathrm{~cm}$ dimensions. The clay pots were filled with $10 \mathrm{~kg}$ clay soil. (180 pots). Plant extracts (Oils of garlic, onion, peppermint, clove, olive, clove, flax seed and anise as well as extracts of turmeric, green tea, moringa and red chillies) were sprayed four times (at the middle of April and at one month intervals. The pure tested of the seven oils were bought from National Research Center Laboratory, Dukki, Cairo. The four plant extracts namely (turmeric, green tea, moringa leaf and red chillies) were dried in the shade and washed with distilled water. They were finely grinded to powder. Fifty grams of each plant material of powder form was homogenized by laboratory blender in $200 \mathrm{ml}$ of methanol (96\%) and distilled water (20:80 v/v) for $10 \mathrm{~min}$, and then left in dark glass bottles for $72 \mathrm{~h}$ for complete extraction. The extracts were filtered through thin cheesecloth sheets. The final extracts were collected separately in other dark glass bottles and exposed to $60^{\circ} \mathrm{C}$ in water bath for $30 \mathrm{~min}$ for methanol evaporation. The collected extracts were then stored in a refrigerator at $5^{\circ} \mathrm{C}$ until needed (Ezz-Thanaa et al. 2015). Triton $\mathrm{B}$ as a witting agent was added to all plant extracts before application. Handy sprayers were used. Spraying was done till run off.

Randomized complete design (RCD) was adopted where. 
AKL et al.

During both seasons the following parameters were recorded:

1- Vegetative growth characteristics namely: plant height, stem thickness, number of leaves/plant, number of laterial shoots/plant, main shoot length $(\mathrm{cm})$, number of leaves/shoot, leaf area $(\mathrm{cm})^{2}$ (Ahmed and Morsy, 1999) and dry weight of whole plant.

1- Roots parameters namely root distribution area $(\mathrm{cm})^{2}$ by using graph papers, number of secondary roots/main root, main root length $(\mathrm{cm})$ and dry weight of roots/plant $(\mathrm{g})$.

2- Plant pigments namely chlorophylls a \& b, total chlorophylls and total carotenoids (mg/ 100 g F.W) in the leaves Von-Wettestein, (1957).

3- Percentages of N, P and K, total carbohydrates (Smith et al., 1956) and soluble sugars.

4- Uptake of N, P and K by each transplant (mg/transplant) (Summer, 1985; Wilde et al., 1985 and A.O.A.C, 2000).

The proper statistical analysis was done. Treatment means were compared using new L.S.D. at 5\% (according to Snedecor and Cochran, 1980 and Mead et al., 1993).

\section{RESULTS}

\section{Vegetative growth characteristic:}

It is clear from the data in Tables $(2 \& 3)$ that growth aspects namely plant height, stem thickness, number of leaves/plant, number of lateral shoots/plant, main shoot length $(\mathrm{cm})$, number of leaves/shoot, leaf area $(\mathrm{cm})^{2}$ and dry weight of whole plant were clearly stimulated owing to using any one of the eleven extracts (seven oils of garlic, onion, peppermint, olive, clove, flax seed and anise plus four extracts of turmeric, green tea, moringa leaf and red chillies) each at 5\% over the control treatment. A clear difference were observed on these growth traits among the eleven plant extracts. The best plant extract in this respect was garlic oil followed by turmeric extract and onion oil. Anise oil occupied the last position in this respect. The highest values were recorded on the transplants that received four sprays of garlic oil at 5\%. The untreated transplants had the lowest values. These results were true during both seasons.

\section{1- Root aspects:}

The four root aspects namely number of secondary roots/main root, main root length and dry weight of roots/plant were positively affected by treating the transplants with any one of the eleven plant extracts over the control treatment. Garlic oil ranked the uppermost position followed by 
turmeric extract while anise oil occupied the last position in this respect. Similar results were declared during 2014 and 2015 seasons (Table 4).

\section{2- Chemical components:}

It is evident from the data in Tables $(5 \& 6)$ that treating transplants of Flame seedless grapevines with any one of the eleven plant extract (seven oils of garlic, onion, peppermint, olive, clove, flax seed and anise plus four extracts of turmeric, green tea, moringa leaf and red chillies) each at $5 \%$ was very effective in enhancing chlorophylls a and b, total chlorophylls and total carotenoids as well as percentages of total carbohydrates and soluble sugars and uptake of $\mathrm{N}, \mathrm{P}$ and $\mathrm{K}$ by transplants relative to the control treatment. The beneficial effects of these natural extracts in this respect could be arranged as follows in descending order garlic oil, turmeric extract, onion oil, green tea extract, moringa leaf extract, red chillies extract, peppermint oil, clove oil, olive oil, flax seed oil and anise oil. These results were nearly the same during both seasons.

\section{DISCUSSION:}

The beneficial effects of these plant extracts might be attributed to the higher content of garlic oil from Dipropyl disulfide, Diallyl disulfide, Dimethyl trisulfide, Dimethyl thiophene, Allyl methyl disulfide, Methyl propyl disulfide, Methyl 1-propenyl disulfide, Allyl propyl sulfide, Bis-(1propenyl)-sulfide, Diallyl sulfide, Dimethyl disulfide, Allyl methyl teterosulfide, Allyl propyl trisulfide, Dially trisulfide, Eugenal. (Mnayer et al., 2014), turmeric extract from $\beta$ - Bisabolene, 1.8-Cineol, p-Cymene, $\mathrm{p}$ Cymen-8-ol, Tr-Curcumin, Curlone, Dehydrocurcumin, Myrcene, $\alpha$ Phellandrene, $\beta$ - Phellandrene, $\alpha$ - Pinene, $\beta$-Pinene, Terpinolene, TrTurmerone, Turmerone, Ascorbic acid, ASH, Calcium, Carbohydrate, Fat, Food energy (k Cal), Iron, Niacin, Potassium, Phosphorus, Protein, Riboflavin, Sodium, Thiamine, Water (Shiyou et al., (2011), onion oil from 1-Propenyl propyl disulfide a , Methyl propyl trisulfide, Menthone, Methyl propyl trisulfide, Dimethyl tetrasulfide, Dipropyl trisulfide, Eugenol, 2Methyl-3,4-dithiaheptane, Dipropyl tetrasulfide, Dipropyl disulfide, Allyl propyl sulfide, Dimethy trisulfide (Mnayer et al., 2014), green extract from Theanine.

Theobromine, Caffeine, Gallic acid, Gallocatechin, Epigallocatechin , Catechin, Epicatechin, Epigallocatechin gallate, Gallocatechin gallate, Epicatechin gallate, Catechins gallated (Lee et al., 2014), moringa extract from Vitamins: Betacarotine, E, A, B ${ }_{1}, \mathrm{~B}_{2}, \mathrm{C}, \mathrm{K}$; Minerals : Cu, K, N, P, 
Mg; Amino acids: Lysine, Leucine, Threonine, Isoleucine, Cysteine, Methionine, Tretophane (Compaoré, 2011), red chillies extract from 4hydroxy-4-methyl-2-pentanone, 1-hexadecene, 2-methylpentadecane, Hexadecane, Heptadecane, pentadecanoic acid, 1-heptadecanol acetate, Octadecane, Alloaromadendrene, oleic acid, 2-methyl-3, 13-octadecadienal, 5-eicosene, Cycloeicosane, 1-octadecanamine, 7, 11-hexadecadienal, 9octadecenamide, 3, 6-dimethyl-2, 3, 3a, 4, 5, 7a-hexa hydrobenzofuran, Eicosane, 2-hydroxycyclopentadecanone, Heneicosane, Nonivamide, Nordihydrocapsaicin, Capsaicin, Dihydrocapsaicin, N-vanillyldecanamide, Docosane, Homocapsaicin, homocapsaicin II, Homodihydrocapsaicin, homodihydrocapsaicin II, 2-methyltricosane, Squalene, Tetracosane, Pentacosane, Hexacosane, Heptacosane, vitamin E, ergost-5-en-3-ol, 11decyldocosane, $\beta$-sitosterol, $\alpha$-amyrin, $\beta$-amyrin, methyl 3 -hydroxycholest5-en-26-oate (Wesołowska et al., 2011), peppermint oil from Menthol, Menthone, trans-carane, Isomenthol, (+)-carvone, 1,8-cineole, mint furanone, Pulegone, mono-(2-ethyl hexyl) ester, menthyl acetate (Tsai et al., 2013), clove oils from 2-Heptanone, $\alpha$-Pinene, Limonene+1, 8 Cineole, 2 -Heptyl acetate, (E)- $\beta$-Ocimene, 2-Nonanone, Linalool, Methyl salicylate, p-Allyl phenol, Eugenol, $\alpha$-Copaene, $\beta$-Caryophyllene, $\alpha$-Humulene, $\Delta$ Cadinene, Eugenyl acetate, Caryophyllene oxide, 2(12), 6(13)Caryophyllen-dien-5-ol (Alma et al., 2007), olive oil from more than twelve fatty acids (oleic, linoleic, palmitic, etc) (Mousa, 2016), flax seed oil from Fats $\%$ Proteins $\%$, Fibre\%, Carbohydrates\%, Alanine , Arginine , Aspartic acid , Cystine, Glutamic acid, Glycine, Histidine*, Isoleucine*, Leucine*, Lysine*, Methionine*, Phenylalanine*, Proline, Serine, Threonine*, Tryptophan * c, Tyrosine, Valine*, Palmitic acid, Stearic acid, Oleic acid, Linoleic acid, Linolenic acid (Popa et al., 2012) and anise oil from Estragol, Cis anethole, Trans-anethole, Elemene (delta), Beta elemene, $\alpha$ himachalene, Gamma- himachalene, $\alpha$ - amorphane, (E)- Methylisoeugenol, $\alpha$ - zingiberene, $\beta$-himachalene, $\alpha$ - muurolene, $\beta$-bisabolene, Betasesquiphellandrene (Ullah et al., 2014).

The rich in nutrients and antioxidants of these plant extracts surely reflected on protecting the plant cells from senescence and disorders as well as enhancing cell division, the biosynthesis of natural hormones such IAA and ethylene, nutrient and water uptake, photosynthesis, building of plant pigments and proteins, amino acids and plant metabolism. These important functions of vitamins were surely reflected on enhancing growth and vine nutritional status in favour of enhancing yield and fruit quality. (Robinson, 1973) as well as enhancing cell division, photosynthesis and most organic foods (Nijjar, 1985). 
These results are in harmony with those obtained by Abdelaal and Aly (2013); Ahmed et al (2013); Abada (2014); Ahmed et al (2014); Uwakiem , (2014);Ahmed et al (2015); Ahmed (2016); Abada et al (2017); IbrahimAsmaa (2017) and Farag-Rana (2017) on different fruit crop species.

Conclusively, for promoting vigorous Flame seedless grapevine transplants, it is necessary to spray the transplants four times (mid of Apr., May, June and July) with garlic oil or turmeric extract each at $5 \%$.

\section{REFERENCES}

A. O. A. C. (2000): Official Method of Analysis. Association of Official Agricultural Chemists. $15^{\text {th }}$ Ed., Published by A.O.A.C. Washington, D.C.(U.S.A.) pp. 490-510.

Abada, M.A.M. (2014): A comparative study for the effect of green tea extract and some antioxidants on Thompson seedless grapevines. International Journal of Plant \& Soil Science, 3 (10): 1333-1342

Abada, M.A.M; El-Salhy, A.M. and Abd El-Hafeez, G.N. (2017): Effect of some plant extracts spraying on growth and fruiting of Flame seedless grapevines. Assiut J. of Agric. Sci., 22(1): 83-99.

Abdelaal A. M.H.A. and Aly, M.M. (2013): The synergistic effects of using turmeric with some antioxidants on growth, vine nutritional status and productivity of Ruby seedless grapevines. Hort. Science Journal of Suez Canal Univ., Vol. 1: 305-308.

Ahmed, E.F.S. (2016): Impact of spraying Moringa oil and turmeric extract on fruiting of Barhee date palms. J. Biol. Chem. Environ. Sci., 11(3): 359-365.

Ahmed, F.F. and Morsy, M.H. (1999): A new method for measuring leaf area in different fruit species. Minia J. Agric. Res. 8 Develop., (19): 97105.

Ahmed, F.F.; Abdelaal, A.H.M.; El- Morsy, S.M.A.; and Shoug, M.A.F. (2015): Impact of spraying some plant extracts on fruiting and storability of Balady mandarin trees. World Rural Observations, 7 (3): 67-75.

Ahmed, F.F.; Ibrahim, M.I.H., Abada, M.A.M. and Osman, M.M.M. (2014): Using plant extracts and chemical rest breakages for breaking and dormancy and improving productivity of Superior grapevines growing under hot climates. World. Rural Observ., 6 (3): 8-18. 
Ahmed, F.F.; Mansour, A.E.M.; Montasser, M.A.A.; Merwad, M.A. and Mostafa, E.A.M. (2013): Response of Valencia orange trees to foliar application of Roselle, turmeric and seaweed extracts. J. Applied Science Research, 9(1): 960-969.

Alma, M. H., Ertas, M., Nitz, S., and Kollmannsberger, H. (2007): Chemical composition and content of essential oil from the bud of cultivated Turkish clove (Syzygium aromaticum L.). BioResources, 2(2): 265-269.

Bhanu, P.; Priyanka S.; Shilpec, Y.; Singh, S.C. and Dubey, N.K. (2013): Safety profile assessment and efficacy of chemically characterized Cinnamomum glaucescens essential oil against storage fungi, insect, aflatoxin secretion and as antioxidant. Food Chemical Toxicology, 43: 446-475.

Compaoré W.R., Nikièma P.A., Bassolé H.I.N., Savadogo A., Mouecoucou J.,Hounhouigan D.J. and Traoré S.A. (2011): Chemical Composition and Antioxidative Properties of Seeds of Moringa oleifera and Pulps of Parkia biglobosa and Adansonia digitata Commonly used in Food Fortification in Burkina Faso. Current Research Journal of Biological Sciences, 3(1): 64-72

Ezz- Thanaa, M.; Aly, M.A., Ahmed, Ekbal, Z.A.; Awad- rehab, M. and Abd El- Gawad, M.G. (2015): Improving Washington Navel orange fruits by some natural pre- harvest foliar applications. J. Adv. Agric. Res. (Fac. Agric. Saba Basha), 20(1): 66-85.

Farag-Rana. S.R. (2017): Effect of spraying turmeric and Roselle extracts on yield and quality of Superior grapevines. M.Sc. Thesis. Fac. of Agric. Minia. Univ., Egypt.

Ibrahim-Asmaa, A. (2017): Effect of foliar application of Moringa loeifera extract on fruiting of Superior grapevines. H. Biol. Chem. Environ. Sci., Vol. 12(1): 559-576.

Lee, L. S., Kim, S. H., Kim, Y. B., and Kim, Y. C. (2014). Quantitative analysis of major constituents in green tea with different plucking periods and their antioxidant activity. Molecules, 19 (7): 9173-9186.

Mead, R. Currnow, R.N. and Harted, A.M. (1993): Statistical Methods in Agricultural and Experimental Biology. $2^{\text {nd }}$ Ed. Chapman and Hall, London pp. 10-44.

Mnayer, D., Fabiano-Tixier, A. S., Petitcolas, E., Hamieh, T., Nehme, N., Ferrant, C., Fernandez, $X$ and Chemat, F. (2014): Chemical composition, antibacterial and antioxidant activities of six essentials oils from the Alliaceae family. Molecules, 19(12), 20034-20053. 
Mousa, A.M. (2016): Evaluation of growth and fruiting of some olive cultivars grown under Siwa conditions. M.Sc. Thesis Fac. of Agric. Minia Univ. Egypt.

Nijjar, G.S. (1985): Nutrition Of Fruit Trees. Published by Kaylyani Publishers, New Delhi, India-. 179 - 272.

Peter, K.V. (1999): Information on turmeric and ginger. Indian Species, 6: (2\&3) : 12-1 4.

Popa, V.M.; Gruia, A.; Raba, D.; Dumbrava, D.; Moldovan, C.; Bordean, D., and Mateescu, C. (2012): Fatty acids composition and oil characteristics of linseed (Linum Usitatissimum L.) from Romania. J. Agroalimentary Processes and Technologies, 18 (2): 136-140.

Robinson, F.A. (1973): Vitamins Phytochemistry Vol. III: 195-198 Lawrence P. Miller (Ed.) Van Nostrand Rinhold. Comp. New York.

Shiyou, L., Yuan, W., Deng, G., Wang, Ping., Yang, P. and Aggarwal, B. (2011): Chemical composition and product quality control of turmeric (Curcuma longa L.). Stephen F Austin State Univ., SFA Sholarworks.

Smith, F.; Gilles, M.A. Hamlton, J.K. and Godees, P.A. (1956): Colorimetric methods for determination of sugar and related substances. Annals. Chen, $28: 350-356$.

Snedecor GAV, and Cochran, G.W. (1980): Statistical Methods. $7^{\text {th }}$ Ed. Iowa State Univ. Press. Ames, Iowa, U.S.A 507.

Summer, M.E. (1985): Diagnosis and Recommendation Integrated System (DRIS) as a guide to orchard fertilization. Hort. Abst., 55 (88): 7502.

Tsai, M. L., Wu, C. T., Lin, T. F., Lin, W. C., Huang, Y. C., and Yang, C. H. (2013). Chemical composition and biological properties of essential oils of two mint species. Tropical Journal of Pharmaceutical Research, 12(4): 577-582.

Ullah, H., Mahmood, A., and Honermeier, B. (2014). Essential oil and composition of anise (Pimpinella anisum L.) with varying seed rates and row spacing. Pak J. Botany, 46: 1859-1864.

Uwakiem, M.Kh. (2014): The synergistic effect of spraying some plant extracts with some macro and micro nutrients of Thompson seedless grapevines. International Journal of Plant \& Soil Science, 3(10): 12901301.

Von-Wettstein, D. V. (1957): Chlroophyll- Lethalc under submikroshopishe formilkechrel der plastiden celi, prp. Trop. Res. Amer. Soc. Hort. Sci., 20 pp. 427 - 433.

Wesołowska, A., Jadczak, D. and Grzeszczuk, M. (2011): Chemical composition of the pepper fruit extracts of hot cultivars (Capsicum annuum, L.). Acta. Sci. Pol., Hortorum Cultus, 10(1) :171-184. 
Wilde, S. A.; Corey, R. B.; Layer, J. G. and Voigt, G. K. (1985): Soils and Plant Analysis for Tree Culture. Mohan Primlani, Oxford \& IBH Publishing Co., New Delhi, India, p 1- 142.

\section{تأثير بعض المستخلصات النباتية علي النمو والحالة الغذائية

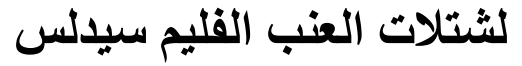

\section{أحمد محمد محمد أبو زيد عقلّ*، محمد على مجاور عباده**، فاطمة

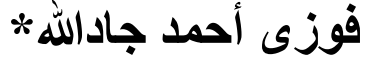

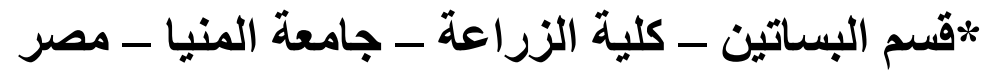 **قمم بحوث العنب - مركز البحوث الزراعية - الجيزة - مصر.}

أجريت تجربة الأصص هذه خلال موسمى 2014 2015، 2015 وذلك لاختبار

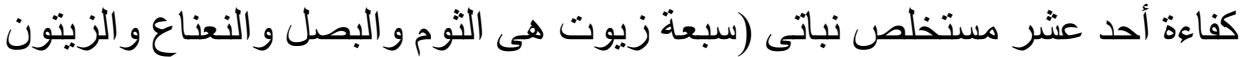

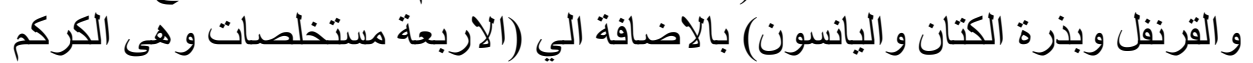

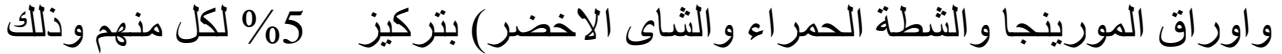
علي النمو والحالة الغذائية لشتلات العنب الفناف الفيم سيدلس.

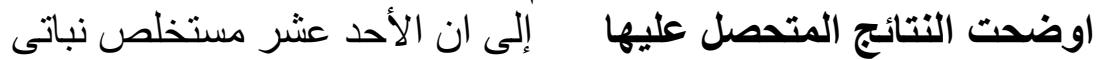

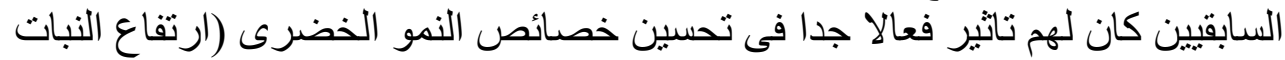

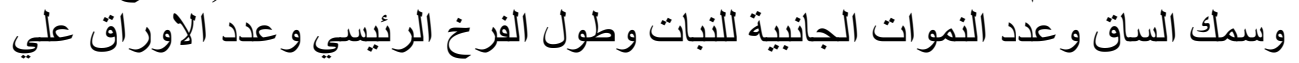

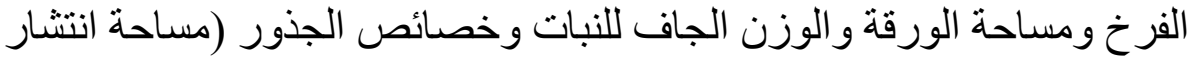

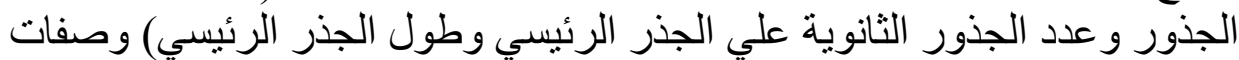

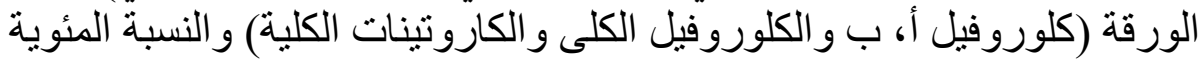

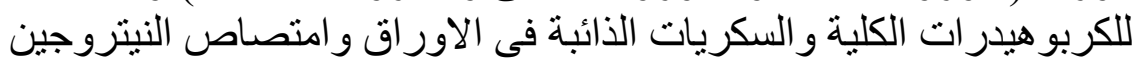

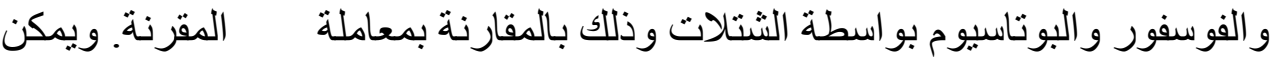

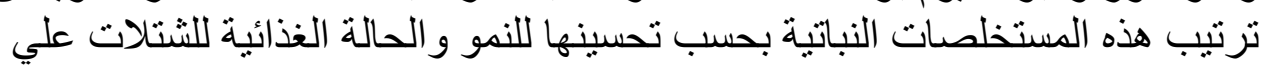

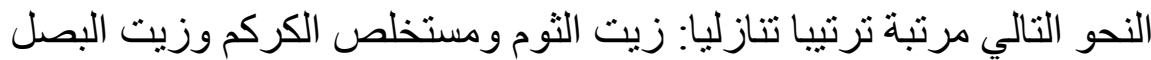

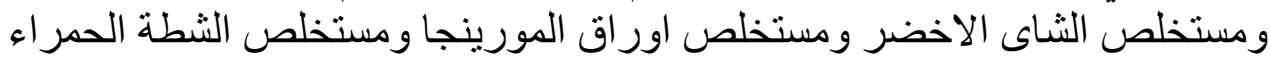

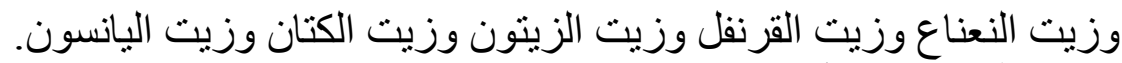

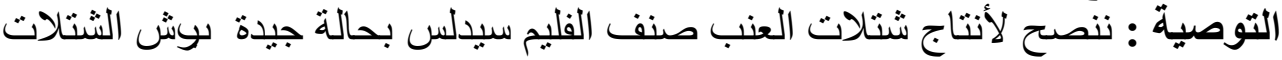

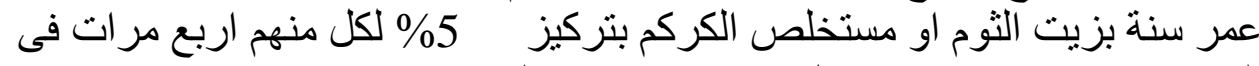
الموسم فى منتصف شهر ابريل ومايو ويونيه ويوليه. 
